ORIGINAL ARTICLE

\title{
The characteristics of human papillomavirus DNA in head and neck cancers and papillomas
}

\author{
T Major, K Szarka, I Sziklai, L Gergely, J Czeglédy
}

J Clin Pathol 2005;58:51-55. doi: 10.1136/icp.2004.016634

See end of article for authors' affiliations

Correspondence to: Dr T Major, Clinic of Otorhinolaryngology and Head and Neck Surgery, Medical and Health Science Centre, University of Debrecen, Hungary, 4012 Debrecen

Nagyerdei krt. 98.

Hungary; majortamas@

freemail.hu

Accepted for publication 18 July 2004

\begin{abstract}
Aim: To determine the prevalence, type, physical state, and viral load of human papillomavirus (HPV) DNA in cases of head and neck cancer and recurrent respiratory papillomatosis (RRP).

Methods: The prevalence and type of HPV DNA was determined in 27 fresh frozen tissue specimens from patients with head and neck cancers and 16 specimens from 10 patients with RRP by MY09/MY1 1 and GP5+/ GP6+ nested polymerase chain reaction (PCR) and subsequent restriction enzyme cleavage. The physical state of HPV DNA was analysed by E1, E2, and E1E2 specific PCRs and Southern blot hybridisation (SBH).

Results: HPV DNA was detected in 13 of 27 cancers and 10 of 10 papillomas. Both low risk HPV-6 and HPV-11 and high risk HPV-16 were present in cancers in low copy numbers, whereas papillomas exclusively harboured low risk HPV-6 and HPV-11. E1E2 PCRs failed to determine the physical state of HPV in cancers except one case where HPV-6 DNA was integrated. In contrast to cancers, all papillomas showed the episomal state of HPV DNA and a relatively higher viral load.

Conclusions: Based on the prevalence, type, physical state, and copy number of HPV DNA, cancers and papillomas tend to show a different HPV DNA profile. The 100\% positivity rate of low risk HPV types confirms the role of HPV- 6 and HPV- 11 in the aetiology of RRP.
\end{abstract}

T he association of high risk human papillomavirus (HPV) types with anogenital cancers is well established. In the past two decades, several authors have detected HPV DNA in head and neck cancers by Southern blot hybridisation $(\mathrm{SBH})$ or polymerase chain reaction (PCR). ${ }^{1-10}$ Among head and neck cancers, HPV DNA positivity tends to show site dependence, with the tonsils, oral cavity, and larynx being the most common sites. ${ }^{1}{ }^{10}$ High risk HPV types 16 and 18 are by far the most predominant types at all sites. ${ }^{31011}$ However, epidemiological data reveal that the role of HPVs in the aetiology of head and neck cancers is rather controversial: the reported frequency of HPV DNA even in the often studied laryngeal site varies between 3\% and $85 \%$ in the literature. ${ }^{8}$ In addition, the prognostic value of HPV DNA positivity is also equivocal. ${ }^{2}{ }^{9}$

Recurrent respiratory papillomatosis (RRP) is the most common benign tumour of the laryngeal epithelium. ${ }^{12}$ Low risk HPV-6 and HPV-11 are the most frequently detected types and are accepted as aetiological agents in RRP. ${ }^{13-16}$

"The product of the E2 open reading frame has a regulatory role in the transcription of the transforming E6 and E7 viral genes"

HPV DNA may exist either in the episomal form or integrated into the host's genome. ${ }^{17-20}$ In the episomal form, the circular double stranded papillomavirus DNA is intact. In contrast, integration results in disruption of the circular viral genome, mainly in the E1E2 open reading frames (ORFs). ${ }^{17} 21$ The product of the E2 ORF has a regulatory role in the transcription of the transforming E6 and E7 viral genes. Disruption of this regulatory role at integration results in increased concentrations of transforming viral proteins E6 and E7, which interact with the p53 and retinoblastoma tumour suppressor proteins, respectively, and therefore alter cell cycle control. ${ }^{21}$ The physical state of HPV DNA tends to correlate with histopathological findings in the uterine cervix. Viral DNA is present as an episome in low grade cervical intraepithelial lesions, whereas the integrated form is predominant in high grade cervical intraepithelial lesions and invasive tumours, although integration is not an essential prerequisite for malignant progression. ${ }^{17} 1822$ Thus, the prognostic role of integration in cervical cancer remains unclear. ${ }^{23} 24$

The physical state of HPV DNA in head and neck tumours has not been widely studied. ${ }^{12526}$ Results of integration studies indicate that HPV DNA can exist either in an integrated or episomal form, or both, in head and neck cancers, and integration is a rare event compared with cervical cancers. ${ }^{126}$ The prognostic relevance of HPV DNA integration in head and neck cancers is unknown.

In our present study, we attempt to determine the prevalence, type, physical state, and copy number of HPV DNA in our study population in the northeast region of Hungary. We must emphasise that both the age standardised incidence and mortality rates of laryngeal cancer in Hungarian men are still the highest in Europe. ${ }^{27}$

\section{MATERIALS AND METHODS}

\section{Patients and clinical specimens}

Fresh frozen tissue samples from 27 patients (26 men, one woman; age, 43-72 years, mean age, 57) with cancers of the larynx and pharynx were collected over a two year period in the clinic of otorhinolarygology and head and neck surgery, University of Debrecen, Hungary. Written informed consent was obtained in all cases. Biopsies for HPV DNA examination were taken from the centre of the lesions. The initial tumour site was laryngeal in 16 cases, hypopharyngeal in four cases, laryngo-hypopharyngeal in two cases, and mesopharyngeal in five cases. According to the TNM criteria, two patients had $\mathrm{Tl}$, eight patients had T2, 15 patients had T3, and two patients had $\mathrm{T} 4$ disease in the primary tumour site. The lymph node status was NO in 15 cases, Nl in seven cases, and N2 in five cases. Haematoxylin and eosin stained sections of all cases were reviewed and the histopathological diagnosis of squamous cell cancer was confirmed.

Abbreviations: HPV, human papillomavirus; ORF, open reading frame; $\mathrm{PCR}$, polymerase chain reaction; SBH, Southern blot hybridisation; RRP, recurrent respiratory papillomatosis 
Table 1 E1, E2, and E1E2 specific PCRs for HPV types 6, 11, and 16

\begin{tabular}{|c|c|c|c|c|}
\hline HPV type & Primer designation & Sequence and genomic position & PCR product & PCR conditions \\
\hline \multirow[t]{3}{*}{6} & E1 & $\begin{array}{l}\text { E1/1: 5'-GGC ACA GCA GGA ATA TTG GA-3' } \\
\text { (nt 1403-1422) } \\
\text { E1/2: 5'-GAT GTT ACT AGC AGA GGT GG-3' } \\
(n+2513-2532)\end{array}$ & $1130 \mathrm{bp}$ & $\begin{array}{l}1 \text { cycle: } 94^{\circ} \mathrm{C}, 2 \mathrm{~min} .40 \text { cycles: } 94^{\circ} \mathrm{C}, 1 \mathrm{~min} ; \\
50^{\circ} \mathrm{C}, 1.5 \mathrm{~min} ; 72^{\circ} \mathrm{C}, 1.5 \mathrm{~min} .1 \text { cycle: } 72^{\circ} \mathrm{C}, \\
2 \mathrm{~min}\end{array}$ \\
\hline & E2 & $\begin{array}{l}\text { E2/1: 5'-TTA GAT GCG TGC CAG GAA CA-3' } \\
\text { (nt 2745-2764) } \\
\text { E2/2: 5'-TGC ACT ATA GGC GTA GCT GA-3' } \\
\text { (nt 3570-3589) }\end{array}$ & $845 \mathrm{bp}$ & \\
\hline & E1E2 & $\begin{array}{l}\text { E1E2L: 5'-CAG GCA CAG CAG GAA TAT } \\
\text { TG-3' (nt 1250-1269) } \\
\text { E1E2R: } 5^{\prime}-\pi G \text { GAC TCC TCG TGC TCG } \pi-3^{\prime} \\
\text { (nt 3436-3455) }\end{array}$ & 2206 bp & \\
\hline \multirow[t]{3}{*}{11} & E1 & $\begin{array}{l}\text { E1/1: 5'-GGC ACA GCA GGA ATA TTG GA-3' } \\
\text { (nt 1688-1707) } \\
\text { E1/2: 5'-GAT GTT ACT AGC AGA GGT GG-3' } \\
\text { (nt 2749-2768) }\end{array}$ & $1081 \mathrm{bp}$ & $\begin{array}{l}\text { As for HPV-6 E1E2 PCR, but annealing } \mathrm{T}=52^{\circ} \mathrm{C} \\
\text { (E1E2 PCR); } 35 \text { cycles }\end{array}$ \\
\hline & E2 & $\begin{array}{l}\text { E2/1: 5'-TTA GAT GCG TGC CAG GAA CA-3' } \\
\text { (nt 2704-2723) } \\
\text { E2/2: 5'-TGC ACT ATA GGC GTA GCT GA-3' } \\
\text { (nt 3734-3753) }\end{array}$ & $1050 \mathrm{bp}$ & \\
\hline & EIE2 & $\begin{array}{l}\text { E1E2L: 5'-CAG GCA CAG CAG GAA TAT } \\
\text { TG - 3' (nt 1391-1410) } \\
\text { E1E2R: 5' - TTG GAC TCC TCG TGC TCG TT-3' } \\
\text { (nt 3306-3325) }\end{array}$ & $1935 \mathrm{bp}$ & \\
\hline \multirow[t]{3}{*}{16} & $E 1^{*}$ & $\begin{array}{l}\text { El/1: nt 1796-1815 } \\
\text { El/2: nt 2863-2881 }\end{array}$ & $1086 \mathrm{bp}$ & $\begin{array}{l}\text { As for HPV } 6 \text { E1E2 PCR, but annealing } \mathrm{T}=55^{\circ} \mathrm{C} \text {; } \\
35 \text { cycles }\end{array}$ \\
\hline & E2† & $\begin{array}{l}E 2 / 1: \text { nt } 2734-2753 \\
\text { E2/2: nt 3853-3872 }\end{array}$ & $1139 \mathrm{bp}$ & \\
\hline & E1E2 $\ddagger$ & $\begin{array}{l}\text { E1E2L: nt 1808-1827 } \\
\text { E1E2R: nt 3532-3551 }\end{array}$ & $1744 \mathrm{bp}$ & \\
\hline
\end{tabular}

Sixteen samples from 10 patients with RRP formed the second study group. Three patients had juvenile onset and seven patients had adult onset RRP. Two samples were available from four patients and three samples were available from one. Disease was limited to the larynx in eight patients, whereas in two patients mesopharyngeal papillomas were also seen in addition to the laryngeal disease. Distal spread to the trachea or bronchi was not diagnosed.

\section{PCR amplification and HPV typing}

After DNA extraction with the standard phenol/chloroform/ isoamylalcohol method the control of DNA integrity was performed using a PCO3/PCO4 PCR protocol, which amplified a 110 bp sequence of the human $\beta$ globin gene. The MY09/ MY11 consensus PCR amplifies an approximately $450 \mathrm{bp}$ sequence from the conserved $\mathrm{Ll}$ region of a large number of mucosotropic HPVs. ${ }^{8}$ After initial denaturation $\left(95^{\circ} \mathrm{C}\right.$ for two minutes) the MY09/MYll PCR consisted of 40 cycles of denaturation at $96^{\circ} \mathrm{C}$ for 20 seconds, annealing at $50^{\circ} \mathrm{C}$ for five seconds, followed by $52^{\circ} \mathrm{C}$ for 15 seconds, and extension at $72^{\circ} \mathrm{C}$ for 90 seconds. A final extension lasted for 90 seconds at $72^{\circ} \mathrm{C}$.

Table 2 The results of HPV prevalence and typing in the cancer group

\begin{tabular}{|c|c|c|c|c|c|}
\hline \multirow[b]{2}{*}{ Site } & \multirow[b]{2}{*}{ HPV positivity } & \multicolumn{4}{|c|}{ HPV type } \\
\hline & & 6 & 11 & 16 & NT \\
\hline Larynx & $8 / 16$ & 2 & 3 & 2 & 1 \\
\hline Hypopharynx & $2 / 4$ & & 1 & 1 & \\
\hline $\begin{array}{l}\text { Larynx + } \\
\text { hypopharynx }\end{array}$ & $2 / 2$ & 1 & & & 1 \\
\hline Mesopharynx & $1 / 5$ & 1 & & & \\
\hline Total & $13 / 27(48 \%)$ & 4 & 4 & 3 & 2 \\
\hline
\end{tabular}

HPV, human papillomavirus; NT, could not be typed by the methods used.
The GP5+/GP6+ consensus PCR, which is also capable of detecting a wide range of HPV types, amplifies an approximately $145 \mathrm{bp}$ sequence inside this PCR product. Initial denaturation $\left(94^{\circ} \mathrm{C}\right.$ for four minutes) was followed by 35 cycles of PCR: denaturation at $94^{\circ} \mathrm{C}$ for 60 seconds, annealing at $48^{\circ} \mathrm{C}$ for 90 seconds, and extension at $72^{\circ} \mathrm{C}$ for 90 seconds, with a final extension for two minutes at $72^{\circ} \mathrm{C}$.

The PCR products were electrophoresed in a $1.5 \%$ agarose gel stained with ethidium bromide, at $100 \mathrm{~V}$ for one hour and visualised under ultraviolet light.

For HPV typing, $5 \mu \mathrm{l} \mathrm{PCR}$ products of the HPV positive samples were mixed with $2 \mu \mathrm{l}(10 \mathrm{U} / \mu \mathrm{l})$ RsaI and $1 \times$ restriction enzyme buffer to a final volume of $20 \mu \mathrm{l}$. After incubation for two hours at $37^{\circ} \mathrm{C}$, the resulting fragments were run on a $21 \%$ non-denaturing polyacrylamide gel and detected by silver staining. Reference plasmids containing the entire HPV-6, HPV-11, HPV-16, and HPV-18 genome were used as standards.

\section{Determination of HPV DNA physical state by E1, E2, and E1E2 specific PCR}

Table 1 provides a summary of the primers, products, and conditions of the E1, E2, and E1E2 specific PCR for HPV types 6,11 , and 16. The PCR amplification mixture consisted of $1 \times$ RedTaq PCR buffer (Sigma, Poole, Dorset, UK) with 1.1mM $\mathrm{MgCl}_{2}, \quad 100 \mu \mathrm{l}$ of each dNTP (Promega, Mannheim, Germany), $0.2 \mu \mathrm{g}$ of each primer, $2.5 \mathrm{U}$ of RedTaq polymerase (Sigma), and $2 \mu \mathrm{l}(0.1-0.3 \mu \mathrm{g})$ of DNA in a final volume of $50 \mu \mathrm{l}$. Amplified products were electrophoresed in 1\% agarose gel (at $100 \mathrm{~V}$ for one hour), stained with ethidium bromide, and visualised under ultraviolet light.

\section{Determination of HPV DNA physical state by SBH}

$\mathrm{SBH}$ was used to determine whether integrated HPV DNA was present in samples positive for the E1E2 specific PCRs. The SBH method used in our study has been published elsewhere in detail. ${ }^{24}$ Briefly, for SBH of HPV-6 and HPV-11 DNA $5 \mu \mathrm{g}$ of genomic DNA was treated as follows. Each 


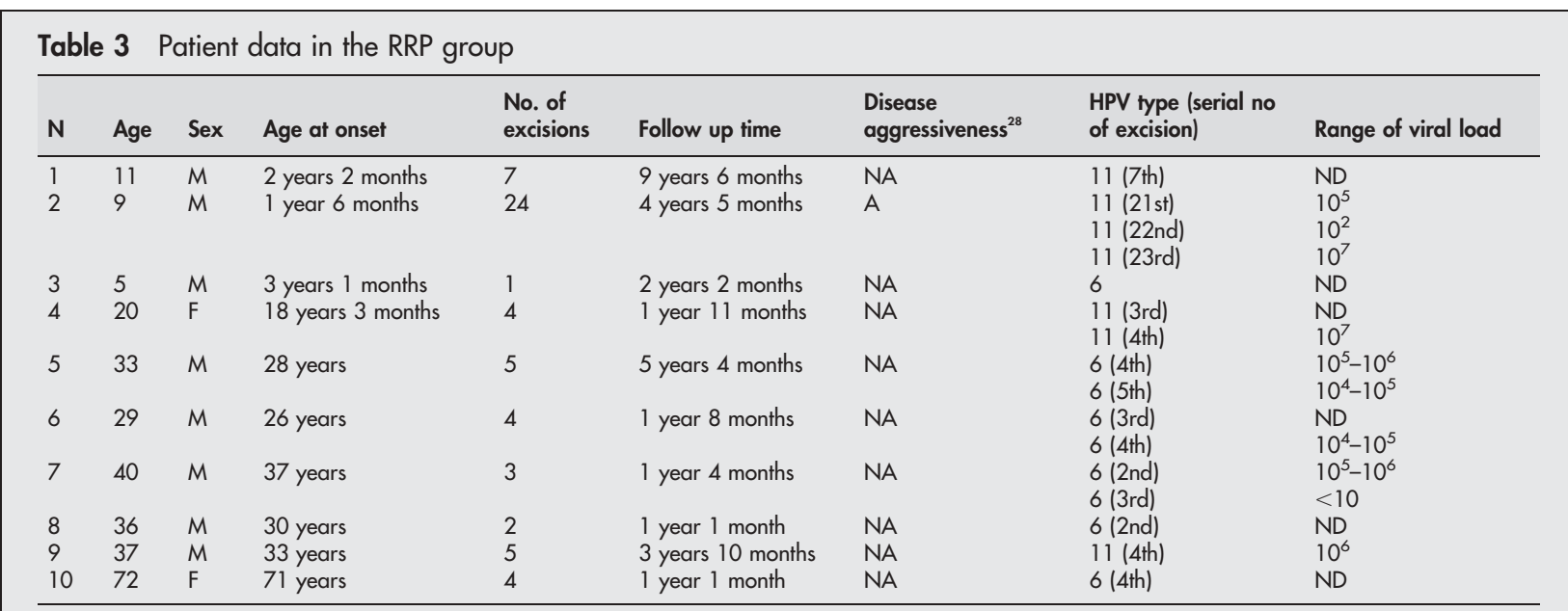

Viral load refers to the HPV DNA copy number of $1 \mu \mathrm{g}$ sample DNA.

A, aggressive disease; F, female; HPV, human papillomavirus; $M$, male; NA, non-aggressive disease; ND, not done; RRP, recurrent respiratory papillomatosis.

sample was digested by EcoRI (non-cut for HPV-6 DNA) and BamHI (one cut) restriction enzymes separately and an undigested control was also included. The episomal and integrated physical states of HPV DNA are distinguished by their different SBH patterns.

The estimation of viral load in cancers and papillomas For calibration, serial dilutions of pBR322 plasmid DNA harbouring HPV-6, HPV-11, and HPV-16 genomes were prepared so that $1 \mu \mathrm{l}$ of the diluted sample contained $2 \times 10^{9}, 10^{9}, 10^{8}, 10^{7}, 10^{6}, 10^{5}, 10^{4}, 10^{3}, 10^{2}$, and 10 copies of the HPV genomes. Subsequently, the MY09/MY1 I PCR was performed on the calibrating serial dilutions. To estimate the viral load of papillomas and cancers the same PCR was performed on $1 \mu \mathrm{g}$ of the sample DNA. In the cancer group, three HPV-6 positive and three HPV-11 positive samples were studied, whereas in the papilloma group, five HPV-6 positive samples of four patients and five HPV-11 positive samples of three patients were studied. After agarose gel electrophoresis of the PCR products, the viral load was estimated by comparing the density of the sample bands to the densities of the calibrating serial dilutions (using Biorad Gel Doc ${ }^{\mathrm{TM}}$ 2000 Gel Documentation System as hardware and Quantity One version 4.0.3 as software; Biorad, Hemel Hempstead, Hertfordshire, UK). In this case viral load refers to the HPV copy number in $1 \mu \mathrm{g}$ of sample DNA.

\section{Comparison of the sensitivities of the MY09/MY11 PCR and the E1E2 PCR}

Both MY09/MY11 PCR and E1, E2, and E1E2 PCRs were performed on 10 fold serial dilutions of the prepared DNA of an HPV-6 positive papilloma.

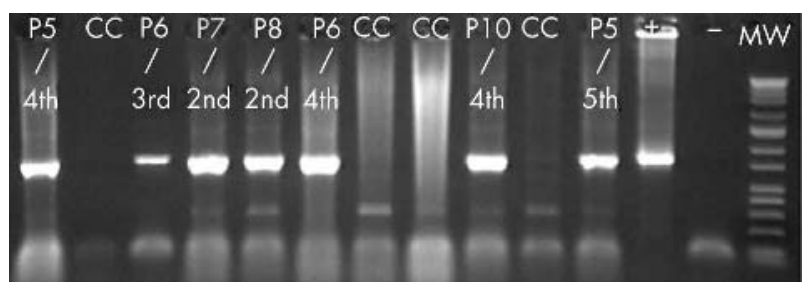

Figure 1 E2 specific polymerase chain reaction for human papillomavirus type 6 (HPV-6) DNA positive samples. Samples P5-P8 and $\mathrm{P} 10$ are derived from papillomas and harbour the examined 845 bp sequence of the HPV-6 E2 gene (for patient and excision number identification see table 3 ); the remaining samples are from cancers (CC); +, plasmid vector containing HPV-6 DNA; -, negative control; MW, Sigma wide range molecular weight marker.

\section{RESULTS}

The overall HPV DNA positivity was $48 \%$. Because of the low sample number from different sites we did not correlate HPV positivity rates or certain HPV types with the initial tumour site. Low risk HPV types 6 and 11 and the high risk HPV-16 showed an approximately even distribution in our carcinoma samples. In two cases, the nested consensus PCR yielded a positive result for the Ll region of HPV but the viral type could not be ascertained by our restriction enzyme cleavage method. No multiple infections were found. Table 2 contains the results of HPV prevalence and typing in the cancer group.

The E1, E2, and E1E2 PCRs were able to determine the physical state in only one case: this specimen was derived from the HPV-6 positive mesopharyngeal cancer and the viral DNA was in the integrated physical state. Based on the positivity of the El PCR and the negativity of the E2 and ElE2 PCRs, the integration site was probably in the E2 ORF. All other HPV DNA positive cancer specimens were negative for E1, E2, and E1E2 PCRs.

In the papilloma group, the HPV positivity rate was $100 \%$. Six cases were positive for HPV-6 and four cases were positive for HPV-11. Tissue specimens from consecutive papilloma excisions of the same patient consistently showed the same viral type. Neither high risk types nor multiple infections were found (table 3 ).

In contrast to the cancer group, all papilloma samples were positive by E1, E2, and ElE2 PCR, indicating an intact E1E2 region (see an example in fig 1 ).

Figure 2 shows an example of the estimation of viral load in HPV-6 DNA positive samples using the calibrating serial dilutions. All examined HPV positive carcinoma samples harboured less than 10 copies of HPV DNA in $1 \mu \mathrm{g}$ of sample DNA. Table 3 summarises the overall results for the viral load of papillomas. In two papilloma cases, two subsequent samples were available for the estimation of viral load, whereas in one case three subsequent samples were available. The HPV DNA copy number tended to vary by several orders during the course of the disease.

Figure 3 shows the comparison of the different sensitivities of the MY09/MY11 PCR and the E1, E2, and E1E2 PCRs. Based on serial dilutions of the PCR products of the different PCRs, the consensus PCR is more sensitive than the ElE2 specific PCRs by approximately three orders of magnitude.

\section{DISCUSSION}

The $48 \%$ overall HPV DNA positivity rate in the cancer group is similar to that seen in other studies. ${ }^{10}$ Differences between 


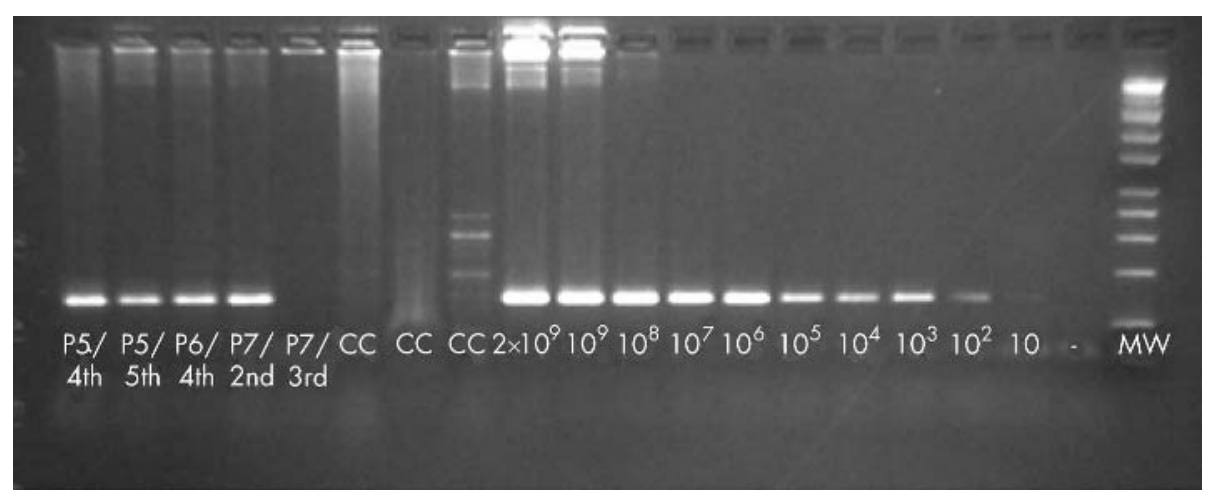

Figure 2 The estimation of viral load in human papillomavirus type 6 DNA positive samples using calibrating serial dilutions. Samples P5-P7 are derived from papillomas (for patient and excision number identification see table 3); CC: cancer samples; $2 \times 10^{9}-10$, the calibrating serial dilutions; - , negative control; MW, Sigma wide range molecular weight marker.

tissue specimens (fresh frozen versus archival), the properties of study populations, the anatomical site, the sensitivity of DNA detection methods (PCR versus SBH or in situ hybridisation), and the differences between statistical methods may account for the highly variable frequency of HPV positivity. ${ }^{70}{ }^{26}$ Even in PCR studies on laryngeal cancer, the HPV DNA frequency varies between $3 \%$ and $85 \%$, which is

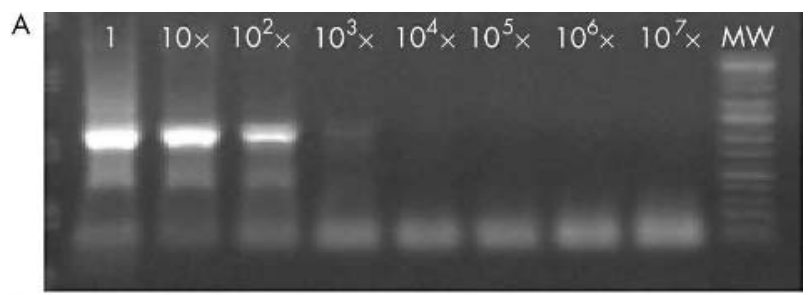

B

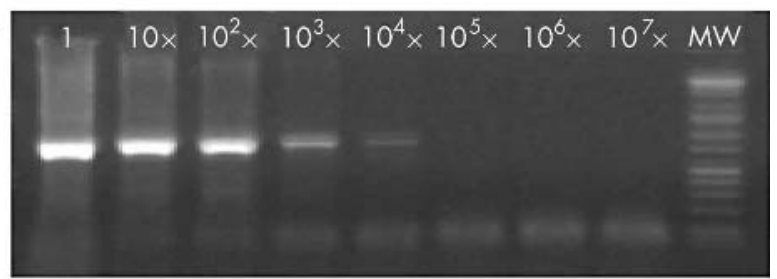

C

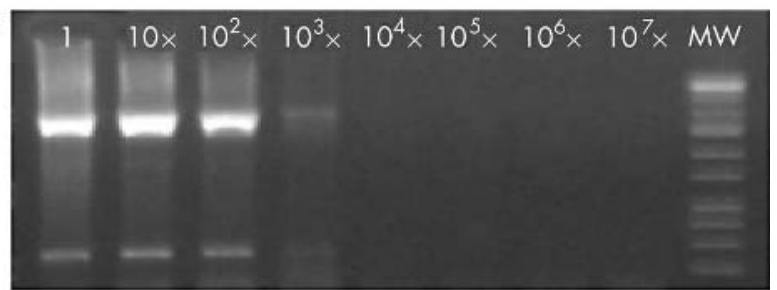

D

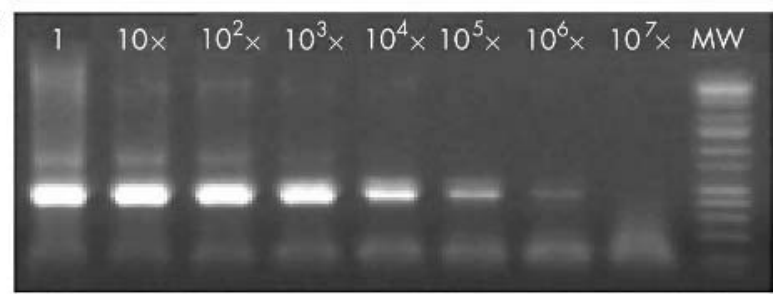

Figure 3 A comparison of the sensitivities of the (A) E1, (B) E2, (C) E1E2, and (D) MY09/MY11 PCRs performed on the same human papillomavirus type 6 (HPV-6) DNA positive papilloma specimen (fourth excision of patient 6 in table 3). Numbers indicate the degree of dilution. MW, Sigma wide range molecular weight marker. E1, E2, and E1E2 PCRs amplify a $1130 \mathrm{bp}, 845 \mathrm{bp}, 2206 \mathrm{bp}$, and $450 \mathrm{bp}$ sequence of the HPV-6 DNA, respectively (table 1). attributable to differences in primers (consensus versus type specific), genomic localisation and length of PCR products, PCR conditions, and false positive results originating from the contamination of samples with HPV DNA. ${ }^{8}$

The presence of low risk HPV DNA in cancer samples has already been described. ${ }^{1626}$ Venuti et al reported five HPV-6 DNA positive cases among 25 laryngeal cancers and one of these five cases harboured the integrated form of viral DNA. The surrounding mucosa contained HPV DNA exclusively in episomal form, even in the case where the tumour itself showed the integrated form. Using the reverse transcriptase PCR technique, no HPV-6 specific mRNA was detected. ${ }^{26}$ Badaracco et al identified 10 HPV-6 positive and three HPV-1 1 positive tumours excised from different head and neck sites, but the integrated form of the virus was present in only one HPV-6 positive laryngeal verrucous cancer. ${ }^{1}$ Of the four HPV-6 positive and four HPV-11 positive cancers in our study, we were able to determine the physical state in only one HPV-6 positive mesopharyngeal case, where the viral DNA was integrated. Matsha et al report HPV-11 as the most predominant type in oesophageal cancers. ${ }^{6}$ The low risk types detected in cancers may either be aggressive mutants or HPV may be only a passenger in neoplasms developed independently from papillomaviruses. ${ }^{26}$

In our opinion, the inability to determine the physical state by E1, E2, and E1E2 specific PCRs in most cancers may be attributable to: (1) the extremely low viral load in cancers (fig 2) and (2) the different sensitivities of the nested PCR and the ElE2 PCRs (fig 3). However, the viral load of the one cancer specimen in which the physical state of HPV DNA could be determined did not differ from that of the other cancer specimens. Detection of the episomal physical state by the E1E2 specific PCRs does not exclude the simultaneous presence of the integrated state. This would have been detected with a characteristic SBH pattern. ${ }^{24}$

There is a consensus in recent studies that by using optimised PCR techniques the frequency of HPV DNA in recurrent respiratory papillomatosis approaches or reaches $100 \%{ }^{141631}$ Our results in the RRP group reaffirm this consensus. In addition to the 100\% HPV DNA positivity the consistent presence of a certain low risk HPV type in serial specimens from one patient also supports the viral aetiology of RRP. The exclusive presence of low risk types HPV-6 and HPV- 11 is also widely accepted..$^{14}{ }^{16}$ In contrast, PeñalozaPlascencia et al report seven different HPV types in patients with juvenile onset RRP. The high frequency of multiple HPV infections and the predominance of HPV-16 DNA in their study might be explained in part by the properties of the study populations. ${ }^{30}$ 


\section{Take home messages}

- Low copy numbers of both low risk human papillomaviruses (HPVs) HPV- 6 and HPV- 11 and high risk HPV16 were present in about half of the head and neck cancers studied, whereas all 10 papillomas exclusively harboured low risk HPV-6 and HPV-11

- The physical state of HPV could not be discerned in the cancers, except for one case where HPV-6 DNA was integrated, whereas all papillomas showed the episomal state of HPV DNA and a relatively higher viral load

- Thus, cancers and papillomas tend to show a rather different HPV DNA profile

- The $100 \%$ positivity rate of low risk HPV types confirms the role of HPV-6 and HPV-11 in the aetiology of recurrent respiratory papillomatosis

There is growing evidence that HPV-11 is associated with a more aggressive clinical course of RRP, including longer periods of disease activity, more surgical treatments needed for each patient, and an increased risk of distal spread and developing squamous cell carcinoma. ${ }^{15} 16$ Doyle et al define the criteria of aggressive RRP as 10 or more total procedures, with three or more procedures within a one year period and/ or spread of disease distal to the subglottis. ${ }^{28}$ In our RRP population, one patient with HPV-11 fulfils these criteria (table 3). However, the low patient numbers and the relatively short follow up time do not allow an evaluation of the prognostic relevance of certain HPV types.

"The consistent presence of a certain low risk human papillomavirus type in serial specimens from one patient also supports the viral aetiology of recurrent respiratory papillomatosis"

In contrast to cancers, the physical state of HPV DNA could be determined in RRP by the E1E2 specific PCRs. SBH also yielded patterns characteristic of the uniform episomal physical state. The episomal state, together with a high viral load, might refer to a productive viral infection. The viral load of papillomas can change during the course of disease, as shown by the serial samples of patients 2,5 , and 7 (table 3 ). These alterations might reflect the antiviral immunity. The prognostic or therapeutic value of viral load needs further investigations on larger study groups.

In conclusion, head and neck cancers and papillomas tend to show a different HPV status. Cancers were characterised by an approximately 50\% HPV DNA prevalence and a low viral load. In contrast, papillomas harboured higher copy numbers of episomal low risk HPV DNA, confirming the role of human papillomaviruses in the aetiology of RRP. Finally, the very low patient numbers must be emphasised, especially in the determination of viral load. Further studies are needed with higher numbers of patients with cancer and RRP to confirm our findings.

\section{Authors' affiliations}

T Major, I Sziklai, Clinic of Otorhinolarnygology and Head and Neck Surgery, Medical and Health Science Centre, University of Debrecen, 4012 Debrecen, Hungary

K Szarka, L Gergely, J Czeglédy, Department of Medical Microbiology, Medical and Health Science Centre, University of Debrecen

T Major and K Szarka contributed equally to this study

\section{REFERENCES}

1 Badaracco G, Venuti A, Morello R, et al. Human papillomavirus in head and neck carcinomas: prevalence, physical status and relationship with clinical/ pathological parameters. Anticancer Res 2000;20:1301-6.

2 Clayman GL, Stewart MG, Weber RS, et al. Human papillomavirus in laryngeal and hypopharyngeal carcinomas. Arch Otolaryngol Head Neck Surg 1994; 120:743-8.

3 Fliss DM, Noble-Tpoham SE, McLachlin CM, et al. Laryngeal verrucous carcinoma: a clinicopathologic study and detection of human papillomavirus using polymerase chain reaction. Laryngoscope 1994;104:146-52.

4 García-Milián R, Hernández $\mathrm{H}$, Panadé $\mathrm{L}$, et al. Detection and typing of human papillomavirus DNA in benign and malignant tumours of laryngeal epithelium. Acta Otolaryngol (Stockh) 1998;118:754-8.

5 Hoshikawa T, Nakajima T, Uhara H, et al. Detection of human papillomavirus DNA in laryngeal squamous cell carcinomas by polymerase chain reaction. Laryngoscope 1990; 100:647-50.

6 Matsha T, Erasmus R, Kafuko AB, et al. Human papillomavirus associated with oesophageal cancer. J Clin Pathol 2002;55:587-90.

7 Mineta H, Ogino T, Amano HM, et al. Human papilloma virus (HPV type 16 and 18) detected in head and neck squamous cell carcinoma. Anticancer Res 1998; 18:4765-8.

8 Lindeberg H, Krogdahl A. Laryngeal cancer and human papillomavirus: HPV is absent in the majority of laryngeal carcinomas. Cancer Lett 1999;146:9-13.

9 Pintos J, Franco EL, Black MJ, et al. Human papillomavirus and prognoses of patients with cancers of the upper aerodigestive tract. Cancer 1999;85:1903-9

10 Snijders $\mathbf{P}$, van den Brule A, Meijer C, et al. HPV and cancer of the aerodigestive tract. Papillomavirus Report 1995;6:157-62.

11 Almadori G, Cadoni G, Cattani P, et al. Human papillomavirus infection and epidermal growth factor receptor expression in primary laryngeal squamous cell carcinoma. Clin Cancer Res 2001;7:3988-93.

12 Shykhon M, Kuo M, Pearman K. Recurrent respiratory papillomatosis. Clin Otolaryngol 2002;27:237-43.

13 Abramson AL, Steinberg BM, Winkler B. Laryngeal papillomatosis: clinical, histopathologic and molecular studies. Laryngoscope 1987;97:678-85.

14 Gabbott M, Cossart YE, Kan A, et al. Human papillomavirus and host variables as predictors of clinical course in patients with juvenile-onset recurrent respiratory papillomatosis. J Clin Microbiol 1997;35:3098-103.

15 Hartley C, Hamilton J, Birzgalis AR, et al. Recurrent respiratory papillomatosis - the Manchester experience, 1974-1992. J Laryngol Otol 1994; 108:226-9.

16 Rabah R, Lancaster WD, Thomas R, et al. Human papillomavirus-11associated recurrent respiratory papillomatosis is more aggressive than human papillomavirus-6-associated disease. Pediatr Dev Pathol 2001;4:68-72.

17 Cullen A, Reid R, Campion M, et al. Analysis of the physical state of different human papillomavirus DNAs in intraepithelial and invasive cervical neoplasm. J Virol 1991;65:606-12.

18 Daniel B, Mukherjee G, Seshadri L, et al. Changes in physical state and expression of human papillomavirus type 16 in the progression of cervical intraepithelial neoplasia lesions analysed by PCR. J Gen Virol 1995;76:2589-93.

19 Jeon S, Lambert PF. Integration of human papillomavirus type 16 DNA into the human genome leads to increased stability of E6 and E7 mRNAs: implications for cervical carcinogenesis. Proc Natl Acad Sci U S A 1995; 92: 1654-8.

20 Jeon S, Allen-Hoffmann BL, Lambert PF. Integration of human papillomavirus type 16 into the human genome correlates with a selective growth advantage of cells. J Virol 1995:69:2989-97.

21 Park JS, Hwang ES, Park SN, et al. Physical status and expression of HPV genes in cervical cancers. Gynecol Oncol 1997;65:121-9.

22 Das BC, Sharma JK, Gopalakrishna V, et al. Analysis by polymerase chain reaction of the physical state of human papillomavirus type 16 DNA in cervical preneoplastic and neoplastic lesions. J Gen Virol 1992;73:2327-36.

23 Vernon SD, Unger ER, Miller DL, et al. Association of human papillomavirus type 16 integration in the E2 gene with poor disease-free survival from cervical cancer. Int J Cancer 1997;74:50-6.

24 Szarka K, Veress G, Juhász A, et al. Integration status of virus DNA and p53 codon 72 polymorphism in human papillomavirus type 16 positive cervical cancers. Anticancer Res 2000;20:2161-8.

25 Snijders PJ, Meijer CJ, van den Brule AJ, et al. Human papillomavirus (HPV) type 16 and $33 \mathrm{E} 6 / \mathrm{E} 7$ region transcripts in tonsillar carcinomas can originate from integrated and episomal HPV DNA. J Gen Virol 1992;73:2059-66.

26 Venuti A, Manni V, Morello R, et al. Physical state and expression of human papillomavirus in laryngeal carcinoma and surrounding normal mucosa. $J$ Med Virol 2000;60:396-402.

27 Bray F, Sankila R, Ferlay J, et al. Estimates of cancer incidence and mortality in Europe in 1995. Eur J Cancer 2002;38:99-166.

28 Doyle DJ, Gianoli GJ, Espinola T, et al. Recurrent respiratory papillomatosis: juvenile versus adult forms. Laryngoscope 1994;104:523-7.

29 Chen CM, Shyu MP, Au LC, et al. Analysis of deletion of the integrated human papillomavirus 16 sequence in cervical cancer: a rapid multiplex polymerase chain reaction approach. J Med Virol 1994;44:206-11.

30 Peñaloza-Plascencia M, Montoya-Fuentes $\mathrm{H}$, Flores-Martinez SE, et al. Molecular identification of 7 human papillomavirus types in recurrent respiratory papillomatosis. Arch Otolaryngol Head Neck Surg 2000;126:1119-23. 